\title{
Development of Support System of Psychological Tests of Drivers for the Police
}

\author{
Arkadiusz Letkiewicz, Izabela Nowicka, Ewa Kuczyńska \\ The Police Academy, Szczytno, Poland
}

\begin{abstract}
Background/Objectives and Goals: The aim of the publication is to present the results of tests obtained through the use of method of examining documents consisting of literature, normative and source acts study, on creating the system which supports the psychological test (battery of psychological tests) of Police drivers, including the drivers of enforcement vehicles of the Police. The system in its assumption should, among other things, enable the evaluation of intellectual efficiency, psychomotor capability and personality (in accordance with the detailed guidelines of annex 6 to the Ministerial Order of 8 July 2014 regarding psychological tests of drivers steering the vehicles with the use of the tools of the proven accuracy, accuracy above 0.7 , objective, standardized and normalised within the group of police drivers). The described tests are conducted based on the grant, financed by the National Centre for Research and Development for the implementation of development project titled "Development of support system of psychological tests of drivers for the Police" No. DOB-BIO6/19/98/2015. Methods: The method of examining documents in the form of indirect observation enabled the analysis of national as well as international acts and acts applied in the European Union. The rulings of the Court of Justice of the European Union, the Polish Constitutional Tribunal and National Judicial Council were also subjected to the analysed tests. The method of examining documents, which provides the opportunity to avail of doctoral sources, was applied in the tests of the dogmatic character. The views of the representatives of individual fields of science concerning the matters connected with the issues of creating fully functioning, implemented system, that is one satisfying the requirements of the highest, IX level of preparedness of the main project, also concerning the law regulations, were presented. Results: As a result of the development of the project, a new fully functioning system supporting the psychological test of police drivers, including the drivers of enforcement vehicles will be created which will be based on the modern IT technologies and will operate in the police PSTD network. The system will meet all the current legal requirements and quality requirements dedicated to psychological diagnostics; it will be equipped in accordance with standards and optimized in terms of diagnostic relevance. The system will allow for an efficient management of documentation of the tests and informing the subjects (results, advice, recommendations). Such understood system will be implemented in the Police allowing the Police for an independent conduct of required by the law regulations psychological tests of drivers through the usage of the existing staff of the psychological police studios and without extra costs connected with the outsourcing of the external psychological tests. In its assumptions, the project is supposed to contribute to the realization of the European Road Safety Action Programme for the years 2011-2020. Two aims connected with the realization of the described project, that is the
\end{abstract}

Arkadiusz Letkiewicz, Ph.D., professor, The Police Academy.

Izabela Nowicka, Ph.D., Associate professor, The Police Academy.

Ewa Kuczyńska, Ph.D., Assistant professor, The Police Academy. 
improvement of the execution of road traffic rules and promoting the use of modern technology to increase road safety, were set out within its assumptions.

Keywords: management, communication, psychology, driver, alcohol

\section{Introduction}

Human being is always the key contributing factor within the road safety system. On the one hand, a person is a co-creator of traffic while on the other hand, he/she is a user of the road. The secure functioning of a driver in traffic depends in a great measure on his/her mental capabilities, social adaptation, driving behaviour, social discipline, emotional control, the capacity to cope with the complex situation of driving a vehicle. Traffic accidents occur both due to mental imperfections of the participants of traffic, as well as their breaking of rules and the lack of abilities to steer the vehicle. Steering a vehicle is the arrangement of co-related possibilities, knowledge, skills, attitudes and emotions of a person. The traffic system contains three inseparable elements, such as: the man, the vehicle and the road. The participation in traffic is a complex system of activities and behaviours in a specific spatial situation by forming relationships with others (Bąk \& Bąk-Gajda, 2008). A peculiar role in such situations is played by vehicles and, more specifically, by the drivers of emergency and enforcement vehicles. Those are first of all the Police officers, Fire Brigade officers, Border Guards and representatives of other services which are responsible for the security of citizens and state security. That is why, specially designated for them tests ought to be elaborated as well as solutions which would shape their behaviour on the road for the security of all participants of traffic.

The shaping of structural organisation of one of the elements of the national system, resulting from the social-economic and political changes cannot take place in isolation with legal changes resulting from the same reasons. The activities, structure, tasks of the police are based on the rules developed by the legislation, doctrine and directive proceedings resulting from them (Płowucha, 1995). The rule of lawfulness understood as the rule of obeying the law by the authorities deserves peculiar attention in the aspect of Police actions as public authorities. It is connected with the legal treatment of the authoritative activities of state bodies both in the sphere of constituting, as well as applying the law. The Police is supposed to be a guarantee of the realisation of declared by the state basic freedoms and rights of persons and citizens. In other words, despite the fact that formally obeying the law is a necessary condition, the law cannot be isolated from its social functions, aims and important social values, which realisation, as it was mentioned, is conducted among others by the Police (retrieved March 12, 2016, from http://pl.wikiedia.rg/wiki/praworz).

\section{Polish Regulations}

In accordance with the content of Article 1 (1) of the Act on Police: "The Police is an armed and provided with uniforms formation which serves the society and is dedicated to protect and secure the citizens and to maintain law and order". The realisation of such activities requires the proceedings in accordance with the laws in force but also the use of supportive technological measures, such as among others vehicles. Steering the enforcement vehicles places great efficiency and personal demands. In the USA in 2012, 83 persons died in the accidents involving police cars (including 35 of them operating on the signal). Polish statistics are not available, but the reports about the accidents at the fault of emergency and enforcement vehicles are not uncommon. The need of test of the predispositions of the police drivers results from the fact that their actions demand the 
orientation in surroundings (Steenbruggen, Borzacchiello, Nijkamp, \& Scholten, 2011) and the prediction of both elements of physical surrounding, as well as the actions of others, because the appearance of a vehicle operating on a signal is a special situation which causes chaotic behaviours. It is important to remember that the vehicle is equipped with systems which service, during the steering of a vehicle, requires the divisibility of attention (Yager, Pitchers, Flagel, \& Robinson, 2015).

Regulation of the Minister of Health concerning the test of drivers establishes an obligation of using methods which have been verified in a psychometric way. Most tests which are used today do not comply with that condition, that is why they should be eliminated by the end of 2016. Regulation of the Minister of Health of 8 July 2014 on the psychological tests of persons who apply for the driving rights, drivers and people working as drivers points out the spheres which should be psychologically examined, that is the evaluation of intellectual capacity, psychomotor capability and personality (with particular focus on social maturity and the ability to perform in difficult situations), as well as the psychomotor capacity. Concerning the methodology of conducting such kind of an tests, the regulation does not precisely determine the type of applied tools. It only informs that the tests, methods and machines used in the test should help to verify the features and skills of persons who work as drivers. They should also meet the conditions of standardization, objectivity, normalisation, diligence and accuracy. Because of that, the psychological studios functioning on the territory of our country and dealing with the tests of drivers apply any process they chose, among those which are available in the market, and the tools of psychological diagnostics. The lack of unification in the field of test methodology causes that drivers applying for a test who are police and military police officers obtain the ruling based on the psychological tests conducted through the usage of various methodologies. As a result of the realization of the proposed project, the complex, standardised system of psychological diagnostics of the drivers of Police and Military Police will be drawn up. The system will be supported by the authorized psychologists (the staff of the Police and Military Police) and it will eliminate the outsourcing of psychological tests to the external subjects which operate in accordance with their own various methods (the development project titled "Development of support system of psychological tests of drivers for the Police" No. DOB-BIO6/19/98/2015).

The expectations concerning developing the solutions which would improve the realisation of the Police actions in the field of an individual conduct of the required by law psychological tests of drivers by the existing staff of police psychological studios enforce the need for interdisciplinary tests. In this aim, the scientific and industrial consortium, which leader is The Police Academy in Szczytno (Poland) obtained a grant for the realisation of a development project titled "Development of support system of psychological tests of drivers for the Police" No. DOB-BIO6/19/98/2015 in the framework of the competition 7/2014 for developing projects in fields of scientific research or development works for defence and security of the state of the National Centre for Research and Development. The system should be realised in the IT technology network which enables direct co-operation with Police Data Broadcasting Network (central server, accessibility from any stand which consists the PTSD workstation), which constitutes the basis of independence and security of obtaining and storing of data. The system should also enable the tests without the necessity of using an extra apparatus apart from appropriately configured computer system. At the same time, the system should be equipped with the device which enables the calibration of methodology of measuring the time of reaction and enable the evaluation of intellectual capacity, psychomotor capability and personality (in accordance with the detailed guidelines of annex 6 to the Ministerial Order of 8 July 2014 regarding psychological tests of drivers steering the vehicles) with the tools of the proven accuracy, accuracy above 0.7 , objective, standardised, and normalised 
within the group of police drivers (the development project titled "Development of support system of psychological tests of drivers for the Police" No. DOB-BIO6/19/98/2015).

The representatives of the practice underline the meaning of men themselves for the human activity, concretely their behaviour which is an outcome of various external, as well as internal factors. It also relates to the secure functioning of a driver in traffic. The conducted tests concerning the safety on roads show the meaning of co-relation between the above mentioned security and the psychological and physical capacities of a driver, their social adaptation, driving behaviour, social discipline, the capacity to cope with the complex situations such as driving a vehicle. Steering the vehicle is the arrangement of co-related possibilities, knowledge, skills, attitudes and emotions of a person. The efficiency in steering a vehicle has three aspects:

(1) physical capacity (determined in the tests);

(2) mental capacity (examined in psychological tests of usefulness for steering vehicles);

(3) knowledge, skills and attitudes of a person steering a vehicle (Bąk, 2004).

However, these issues should be viewed not only in the human (driver's) context as an individual, but also in relation to legal structures in which as a result of being an individual the person found himself/herself. As a preliminary assumption it should be considered that a driver in service of the Police is bound by the same road rules as any other road user (The Act of 20 June 1997, the Act on Road Traffic, Journal of Laws, 2012.1137 consolidated text). Polish legal system defines both the driver of a vehicle who according to art. 3 of an Act of 5 January 2011, Journal of Laws 2015.155 consolidated text, (1) can be a person who reached the required age and who is not physically and mentally disabled, and who fulfils one of the following conditions:

(a) is capable of steering a vehicle in a way that does not endanger road safety, does not hinder the free flow of traffic, does not impair anybody's safety and possesses an appropriate document which confirms the qualifications to steer a vehicle;

(b) takes driving lessons' training;

(c) passes a state exam.

(2) Vehicle driver can also be a person who takes training sessions as part of the initial qualification, summarily initial qualification, complementary initial qualification or complementary summarily initial qualification, referred to in Chapter 7a of an Act of 6 September 2001 on Road Transport (Journal of Laws 2013, item 1414 as amended), and is physically and mentally capable.

(3) Physically disabled person can be a driver if he/she obtained a medical certificate which states the lack of medical restriction to steer a vehicle.

(4) A person not less than 18 years of age is not obliged to possess a document which confirms the qualifications to steer a bicycle, bicycle pushchair or vehicles with animal traction.

(A) The provisions of this act make more precise the criteria for qualitative selection towards a person who can steer an emergency or enforcement vehicle, pointing out in art. $106 \mathrm{sec} .1$ that a person can steer an emergency or enforcement vehicle if:

(1) a person is not less than 21 years of age;

(2) a person possesses a driving licence which is applicable to the relevant vehicle category;

(3) a person obtained a statement:

(a) a medical certificate of no health contraindication for steering an emergency or enforcement vehicle;

(b) psychological certificate of no psychological contraindication of steering an emergency or enforcement vehicle; 
(4) completed a course for steering an emergency or enforcement vehicle;

(5) possesses a permit to steer an emergency or enforcement vehicle in terms of a specific category of driving licence.

(B) The provision of Sec.1 Clause 1 is not applied to the police officers referred to in Art. 8 section 3.

(C) The provision of Sec.1 Clause 4 is not applied to the National Fire Service, the Police, the Border Guard, the Government Protection Bureau, the Prison Service, the Public Transport Inspectorate and the drivers of volunteer fire-fighting teams.

The above provision explicitly points out the necessity of obtaining by the driver of an emergency or enforcement vehicle the statement of no psychological, as well as health contraindications. Such a situation takes place in the context of efforts to obtain qualifications for steering an emergency or enforcement vehicle. But it is necessary to bear in mind the fact of exceptional circumstances which enforce the mentioned tests, because there is a doubt if a given person should use the obtained qualifications. Every psychological test of a driver provides a diagnostic service. The specific kind of a diagnosis constitutes the test of persons in risk categories who are directed for the test pursuant to the act-The Act on Road Traffic, that is persons who were intoxicated during the apprehension, the persons who exceeded the penalty points limit and the perpetrators of road accidents. The aim of this test is a diagnosis whether there exists a correlation between the driver's behaviour (the cause of a road accident) and his/her capabilities and/or personal traits defined as a result of the test. Finding such a link constitutes the basis for prognostic diagnosis - the prediction of the future functioning of the driver in the traffic (The psychological test of drivers as a form of action on health and safety at work, 2008).

Adopting the definition of "security driver" and describing him/her as a person who will steer the vehicle on the road from one place to another collision-free it can be assumed that such a driver:

(1) possesses the appropriate mental capacities;

(2) has mastered and can use all the necessary skills connected with steering the vehicle.

(There is no doubt that it also concerns the person who steers an emergency or enforcement vehicle).

There is an uninterrupted correlation between the type of behaviour, the road situation and the way of its solving undertaken by the driver. The psychologists who examine the predispositions of secure or dangerous behaviours of drivers cannot predict all the factors which would appear in a concrete situation of the risk of an accident. They solely make a diagnosis of those elements to which they predict that:

(1) Firstly, they have a diagnosis and prognostic value in the evaluation of psychical capacities, necessary to steer the vehicles;

(2) Secondly, they diversify the behaviour of individual persons;

(3) Thirdly, they can be examined with the tools available and verified in psychometric way (Bąk, 2004).

Therefore, there is compatibility of laws standardising the necessity of taking up the psychological tests at least with the norms of criminal or administrative law.

In accordance with the above, the development project titled "Development of support system of psychological tests of drivers for the Police" proposes to expand the functionality of the method of data analysis, drawing up the uniform database of drivers and the export model which would support taking up jurisdiction and personal decisions.

(1) Database

The designed system should provide the possibility to carry out tests on drivers of emergency and enforcement vehicles for the internal purposes of the Police and the Military Police (and potentially for the 
purposes of other services subject to the Ministry of the Interior and Administration and to the Ministry of Defense). Currently, the tests are carried out in psychology laboratories subject to the Ministry of the Interior and Administration, specialized laboratories of the Police (Legionowo, Cracow), as well as at external research units. On the one hand, it generates unnecessary costs, while on the other it is related to the heterogeneity of the precise methodology in use, both in terms of testing methods and of accepted standards and judicial decisions.

(2) Decision-making system

The creation of a homogenous database of police enforcement vehicles' drivers will enable the establishment of the decision-making system (DMS) which will function as:

(a) The support for psychologist's decision. The usage of modern methodology of the IRT modeling will make tests shorter in time and their results more precise. Apart from numerical results, the psychologist will get judicial suggestions based on advanced statistical analysis.

(b) The psychometric analysis. The system will collect data to enable current monitoring of the accuracy of decisions which would be made based on the test results, the reliability of measurement, and the updated standards.

(c) The module to generate reports for the purposes of the human resources management.

The system will present strengths and weaknesses of every driver, at the same time suggesting the specific traits based on experience from previously implemented grants.

(3) The assurance of compatibility of the management and the functioning support system of psychological evaluation of candidates for the Police (SYNAPS-System of Psychological Tools). This would enable the flexible management of human resources of police psychologists, the reduction in costs of training, equipment, and software.

These refer to the issue indicated in the title, i.e., the drivers of emergency and enforcement vehicles under the influence of alcohol or other substances having a similar effect.

The ban on using a vehicle by a person in condition of insobriety was first introduced in $\S 51$ (a) of the Regulation of the Minister of Public Works and the Minister of Internal Affairs, in consultation with the Minister of Military Affairs, on the movement of motor vehicles on public roads dated January 27th, 1928. (Regulation of the Minister of Public Works and the Minister of Internal Affairs, in consultation with the Minister of Military Affairs, on the movement of motor vehicles on public roads dated January 27th, 1928, Dz. U. R.P. 1928, no. 41, item 396).

\section{Driving Motor Vehicles under the Influence of Alcohol}

Nonetheless, the regulation does not specify what such a state meas. Although the ban on driving after the consumption of alcohol existed, in practice it was not executed. The driver was punished only after causing an accident while being intoxicated. However, the penalty provided by the Regulation was only administrative, which is the deprivation of driving license (Pyter (Lublin), 2011).

In $\S 53$ point 2(a) of the Regulation of the Minister of Transportation, the Minister of Internal Affairs and the Minister of Military affairs on the movement of motor vehicles on public roads dated October 27th, 1937, issued in consultation with the Minister of Social Welfare, driving motor vehicles in condition of insobriety was banned definitely (Regulation of the Minister of Transportation, the Minister of Internal Affairs and the Minister of Military Affairs, in consultation with the Minister of Social Welfare, on the movement of motor vehicles on public roads dated October 27th, 1937, Dz. U. 1937 no. 85, item 616). Therefore, from January 1st 
of 1938 to December 10th of 1959, by the introduction of the Alcoholism Prevention Act (Dz. U. no. 69, item 434) driving while intoxicated became an offense, since it violated order regulations.

The Penal Code of 1932 (Dz. U. dated July 11th, 1932, no. 60, item 571) did not sanction driving in condition of insobriety. However, the art. 247 provided an imprisonment sanction or a detention order up to 3 years for persons who do not help the ones under immediate imminent danger to life, but could do so without putting themselves or their close ones in danger of personal injury (Decree of the President of the Republic of Poland, the Penal Code dated July 11th, 1932, Dz. U. R.P. 1932 no. 60, item 571).

A breakthrough in legislation related to driving motor vehicles under the influence of alcohol was the passing of the Alcoholism Prevention Act by the Polish Parliament on December 10th, 1959, which introduced the criminal liability for driving in the state of intoxication. The article $28 \S 1$ of the Act provides: "Whoever drives a motor vehicle in condition of insobriety, used as means of land, water or air transportation, shall be penalized by a detention order up to 2 years or by a fine, or shall be subject to both penalties". $\$ 2$ Whoever drives other vehicle in condition of insobriety on a public road, shall be penalized by a detention order up to a year or by a fine of PLN 5000 (Alcoholism Prevention Act dated December 10th, 1959, Dz. U. 1959 r., no. 69, item 434).

In this regulation, the legislator adopted an extensive qualification covering driving motor vehicles in land traffic, as well as in water or air traffic. Additionally, the article 30 of this Act states: "Whoever drives a motor vehicle in condition of insobriety, unintentionally causes the danger of land, water or air transportation crash, shall be penalized by imprisonment up to 5 years or by a detention order". In contrast, the article 31 indicates the loss of the right to drive motor vehicles. Pursuant to the Act, due to the perpetration of criminal offences mentioned above, the perpetrator loses these rights for 6 months and up to 10 years. On the other hand, the article 19 paragraph 1 of the Act on safety and order on public roads dated 27.11.196 banned driving in condition which indicated a consumption of alcohol or other substance having similar effect.

As R. A. Stefański (1999) indicated, the offences defined in article 28 of the Alcoholism prevention Act were mostly penalized by fines; e.g., in the article $28 \S 1$ fines in 1963 accounted for $79 \%$ of predicated penalties, in $1971-88 \%$. The penalty of detention in all circumstances was predicated at a minimal degree (in 1963 they accounted for 13\%, in 1969-2\%).

The Act of the Penal Code dated April 19th 1969, which replaced the previous arrangements of 1932, in article $145 \S 3$ provides that: "When driving a motor or other vehicle in condition of insobriety, the perpetrator is guilty of the offense defined in $\S 1$ or 2 and shall be penalized by imprisonment for a year and up to 10 years" (Act of the Penal Code dated April 19th, 1969, Dz. U. 1969, no. 13, item 94, as amended). Main attributes of an offence defined in article $\S 2$ are fatal and severe injuries or a serious detriment to the health of a person, which result from the breach of principles of security on public roads.

Pursuant to the principles of the Code, all types of the offense of traffic accident wereprosecuted by public indictment, such as low and medium severity traffic accident (article $145 \S 1$ ), high severity traffic accident (article $145 \S 2$ ), qualified traffic accident in view of the driver's condition of insobriety while driving a motor or other vehicle (art. 145 §) (Stefański, 2009).

Nonetheless, this regulation did not refer to the driving of motor or other vehicles after the consumption of alcohol or other substance itself.

The Upbringing in Sobriety and Alcoholism Prevention Act dated October 26th, 1982, in article 46 paragraph 3 states that "the condition of insobriety occurs when the blood alcohol levels are above $0.5 \%$ and it 
leads to the increase of alcohol in the exhaled air above $0.25 \mathrm{mg}$ in $1 \mathrm{dm}^{3 \text { " }}$ (The Upbringing in Sobriety and Alcoholism Prevention Act dated October 26th, 1982, Dz. U. 1982, no. 35, item 230.).

The equivalent for the repealed provision of article 28 of the Alcoholism Prevention Act dated December 10th, 1959 (Dz. U. No. 69, item 434) was the provision of the article 87 of the Act of the Code of Petty Offenses, dated May 20th, 1971 (Dz. U. dated 31.05.1971, no. 12, item 114), which provided that :

$\S 1$ Whoever drives a motor vehicle - used in land, water or air transportation - and is in condition indicating consumption of alcohol or other substance having similar effects, shall be penalized by a detention order or a fine;

$\S 2$ Whoever drives other vehicle than mentioned in $\S 1$ on a public road and is in condition indicating consumption of alcohol or other substance having similar effects, shall be penalized by a detention order up to 2 months or by a fine;

$\S 3$ In case of a minor offense mentioned in $\S 1$, a ban on driving motor vehicles may be predicated if the perpetrator was in the condition of insobriety.

In accordance with the guidelines to the judicial policy in cases of traffic violations of the Minister of Internal Affairs, dated December 24th, 1975 (ZW1/76, pp. 5-10), the concept of "the condition indicating the use of alcohol" is more general than "the condition of insobriety", and it is solely related to the fact of alcohol consumption. The condition indicating the use of alcohol occurs when the blood alcohol levels are above $0.2 \%$ (i.e., the upper limit of the so-called physiological alcohol). This approach also applies to the narrower concept of "the condition of insobriety", which occurs when the blood alcohol levels are above $0.5 \%$ (Bafia, 1980).

"Since the very beginning of implementing the Code of Petty Offenses, the offenses were mostly penalized by fines, and exceptionally by detention orders. The fine accounted for more than $99 \%$ of predicated penalties, e.g., in 1995 it accounted for 99.7\%, in 1996-99.9\%, and in 1997—99.9\%" (Stefański, 1999).

The criminalization of accident-free driving in the condition of insobriety or under the influence of an intoxicant - in case of a motor vehicle in land, water or air traffic (paragraph 1) or other vehicle on a public road, in a residential or a traffic zone - was implemented by the novelization of the Penal Code dated April 14th, 2000.

The equivalent for the article 178(a) of the Penal Code under the Code of Petty Offenses is the article 87 of the Code of Petty Offenses, which states that it is prohibited to drive-in condition after using alcohol or other similarly intoxicating substance — a motor vehicle in land, water or air traffic, or other vehicle on a public road, in a residential or a traffic zone.

The similarity of attributes of these regulation is quite visible.

The only difference refers to the intoxication with alcohol or other intoxicant.

The article 87 of the Penal Code refers to "the condition after using alcohol or other similarly intoxicating substance". In accordance with the Upbringing in Sobriety and Alcoholism Prevention Act, the condition after using alcohol occurs when the blood alcohol levels are equal or increase to:

(1) blood alcohol levels from $0.2 \%$ to $0.5 \%$; or (2) the presence of alcohol in the exhaled air from $0.1 \mathrm{mg}$ to $0,25 \mathrm{mg}$ in $1 \mathrm{dm}^{3}$.

The article 178(a) of the Penal Code refers to the condition of insobriety or being under the influence of an intoxicant.

In accordance with the article 115 paragraph 16 of the Penal Code, the condition of insobriety occurs when: 
(1) blood alcohol levels are above $0.5 \%$, or when it is still increasing; or

(2) the presence of alcohol in $1 \mathrm{dm}^{3}$ of the exhaled air exceeds $0.25 \mathrm{mg}$, or when it is still increasing.

For the perpetrator in condition after using alcohol, the line between a criminal offense and a minor one is drawn by the insobriety limit, whose exceeding has solely a quantitative aspect.

Nonetheless, it shall be taken into account that if the condition after using alcohol exceeds a particular level and turns into the condition of insobriety, it does not eradicate the concept of the condition after using alcohol (e.g., Decision of the Supreme Court of 2002).

The influence of the intoxicant as the attribute of criminal proceedings is presented differently. The difference between the intoxicant and the substance having similar effects to the alcohol is of qualitative nature. There is no measure such as the alcoholic strengths expressed in permille or $\mathrm{mg} / \mathrm{dm}^{3}$. However, based on literary divagations, it may be considered that when any strengths of a substance having similar effects to alcohol are found in driver's blood levels, he or she shall be held liable pursuant to the article 87 of the Code of Petty Offenses under the "negative" condition - the lack of data (based on other evidence, especially witnesses' testimonies) indicative of actual intoxication limiting the ability of safe driving. When the "influence of an intoxicant" is proven, the driver shall not be held liable in accordance with the article 87 of the Code of Petty Offenses, but shall be liable for penal sanction pursuant to the article 178(a) of the Penal Code.

Another changing Act on amending the law dated September 27th, 2013 - the Code of Criminal Procedure and some other acts dated November 9th, 2013, implemented normative changes in terms of the perpetrator's in condition of insobriety driving behaviours on public roads, in residential or traffic zones of vehicles other than motor ones. These proceeding are no longer considered criminal, but are perceived as minor offense. Moreover, the penal measure in the form of a driving ban, so far adjudicated as mandatory, was replaced by an optional mode.

The driver should learn to make a self-assessment of his or hers actual dexterity and ability to adjust behaviour to the results of this self-assessment. Therefore, the decisive factor which affects the driver's behaviour is his or hers psychic performance, which consists of: (1) The possibilities resulting from configuration and mutual relations of psychic predispositions of the driver. These predispositions create a sub-system in which a momentary disorder of one feature (e.g., visual perception) may be compensated or not by other features (e.g., character traits such as carefulness, responsibility, etc.). Psychomotor features, character and temperament traits, and short-term emotional states create the psychic performance of the driver; (2) Knowledge - the information about the functionality of the system that the driver should have, i.e., information about the driving rules, the behaviour of all road users, about the vehicle and the influence of the situation on the road (physical and social) on the manner of driving and on himself, his behaviour and on the levels of mechanisms affecting this behaviour; (3) The abilities and training on responsible participation in traffic. Safe driving requires: the skill of proper use of control devices (turning into habits by training); the skill of proper environmental perception of the road and all changes of situation; the skill of overall assessment of the situation; the skill of assessing own capabilities to act upon a situation (normal or difficult); the skill of making proper manoeuvres and with reference to the features of the current traffic situation, the anticipated behaviours of other drivers, and traffic regulations; and (4) Motivation and approach-factors affecting and changing the driver's behaviour, self-assessment. The proficient functioning of the driver in traffic is conditioned by proper physical ad psychic fitness, and refers to all factors mentioned above (Bąk, 2008). Driving a vehicle after drinking alcohol triggers a number of changes in the driver's process of receiving and interpreting information, and in processes decisive of behaviour: 
(1) it worsens coordination — having trouble with performing simultaneous actions;

(2) it decreases responsiveness - prolonging the time of reaction;

(3) it deteriorates sight - having trouble with seeing details and events on the road;

(4) it limits the purview-narrowing the normal field of view;

(5) it causes incorrect assessment of distance and speed;

(6) it causes incorrect assessment of own abilities (the belief in own skills "one beer won't do any harm");

(7) it interferes with the processes of concentration and divided attention;

(8) it slows down the adaption of sight to darkness;

(9) it increases the susceptibility to glare;

(10) it promotes recklessness, show-offs and aggression (retrieved March 15, 2016, from http://psychotesty-szczecin.pl/po-zatrzymaniu.html).

The criminal law regulations which enable the competent law enforcement authorities to ascertain that the driver was under the influence of alcohol or other substance having similar effects may consequently lead to obligatory psychological tests. It is mentioned in the article 99 of the Act on drivers of vehicles:

1. The District Governor issues an administrative decision of referral...;

(3) psychological test in terms of transport psychology, when:

(a) the driver was driving in the condition of insobriety, after using alcohol or other substance having similar effect;

(b) the driver exceeded the number of 24 points gained by violating road traffic regulations;

(c) during the probation term, the driver has committed two minor offenses in terms of transportation safety;

(d) the driver caused a traffic accident which resulted in other persons' fatal or severe injuries mentioned in the article $156 \S 1$ or article $157 \S 1$ of the Penal Code.

\section{Conclusion}

The results of research conducted on the basis of the grant obtained from the National Centre of Research and Development for the realization of the development project titled "Development of support system of psychological tests of drivers for the Police", No. DOB-BIO7/20/01/2015 will enable:

(1) the objectification of psychological tests of drivers-the elimination of the influence of subjective/personal factors on the test procedure and the interpretation of the results;

(2) the standardization of diagnostic procedure, including the unified (temporarily and individually on a computer screen) presentation system of tests instructions for the purpose of full understanding of the content by the examined persons. The instructions will be shown until the examined person correctly completes all sample tasks;

(3) the time shortening of the diagnosis by the elimination of algorithmic operations, so far realized in accordance with the so-called "calculating by ready-made diagnostic keys". In the proposed system, the results will be calculated automatically by a computer system and will be applied to relevant norms;

(4) the exchange of information between particular psychological laboratories which examine the candidates for drivers and the drivers of the Police and the Military Police. It is particularly important due to the frequent dislocation of the place of service of subjects, as well as the realization of tests (admission, periodic and special ones) at different facilities. Currently, there is no access to previous researches conducted 
throughout the country (lack of control). The proposed system will introduce online access to the so-called "research history" conducted at any facility, and will enable to compare the results for the purpose of the diagnosis, as well as for the purpose of the retrospective evaluation in terms of research appealed to the (higher) second instance against the decision of the psychologist examining at first instance, etc.; and

(5) the making of objectivized decisions in terms of examining the drivers who suffered from injuries resulting from taking part in proceedings, in which there were team members or other bystanders severely or fatally injured. Apart from implementing the project results in terms of national defense and security and economic or social practice, the quantifiable benefits primarily account for: reducing the costs of carrying out obligatory psychological tests, and for improving the management of human resources.

The unquantifiable benefits of the project are:

(1) the increased professionalism of psychological tests (promotional benefits for laboratories);

(2) the increased credibility of diagnosis (less mistakes means better use of human resources); and

(3) the decreased number of accidents among police drivers and better work quality-increased effectiveness of training (better selection of candidates).

Particularly, the system will enable efficient management of research documentation and information for the subjects (results, advice, recommendations).

\section{References}

Bafia, J. (1980). Danuta Egierska, Irena Śmietanka, Kodeks wykroczeń, Komentarz. Warszawa, 212.

Bąk, J. (2004). Psychologiczne badanie kierowców. Bezpieczeństwo Pracy, 6(12).

Bąk, J. (2004). Psychological test of drivers. Safety at Work, 6, 12.

Bąk, J. (2008). Dorota Bąk-Gajda Psychologiczne Czynniki BezpieczeŃstwa Ruchu Drogowego. Eksploatacja I Niezawodność, $3(22)$.

Bąk, J., \& Bąk-Gajda, D. (2008). Psychological factors in road safety. Eksploatacja i Niezawodnośc, 3.

Płowucha, S. (1995). Zagadnienia prawne organizacji i funkcjonowania Policji. Szczytno, 4.

Pyter (Lublin), M. (2011). Prawne zasady użytkowania pojazdów mechanicznych w Drugiej Rzeczypospolitej. Czasopismo prawno-historyczne, Tom LXIII. Zeszyt 2, 99.

Ryszard A. S. (1999). Opinia o projekcie ustawy o zmianie ustawy—Kodeks karny (Druk sejmowy nr 1019) Kancelaria Sejmu. Biuro Studiów i Ekspertyz, Ekspertyza wykonana na zlecenie BSiE, kwiecień 1999. Ekspertyza, 183(2).

Steenbruggen, J., Borzacchiello, M. T., Nijkamp, P., \& Scholten, H. (2011). Mobile phone data from GSM networksfor traffic parameter and urban spatial pattern assessment: A review of applications and opportunities. Geo Journal, 78(2), 223-243. Retrieved http://link.springer.com/article/10.1007/s10708-011-9413-y.

Stefański, R. A. (2009). Wnioskowy tryb ścigania przestępstwa średniego wypadku drogowego. Prokuratura $i$ Prawo, 11-12(28-29).

Stefański, R. A. (1999). Opinia o projekcie ustawy o zmianie ustawy-Kodeks karny (Druk sejmowy nr 1019) Kancelaria Sejmu. Biuro Studiów i Ekspertyz, Ekspertyza wykonana na zlecenie BSiE, kwiecień. Ekspertyza, 183(2).

The psychological test of drivers as a form of action on health and safety at work. (2008). The material for the Meeting of the Labour Protection Council at the Parliament of the Republic of Poland, October 21, 2008, retrieved http://rop.sejm.gov.pl/1_0ld/opracowania/pdf/material1.pdf

Yager, L. M., Pitchers, K. K., Flagel, S. B., \& Robinson, T. E. (2015). Individual variation in the motivational and neurobiological effects of an opioid cue. Neuropsychopharmacology, 40, 1269-1277. 